Volume 3, Nomor 1, Februari 2020, Halaman 33-45

p-ISSN 2615-725X (Print) e-ISSN 2615-8655 (Online)

http://diglosiaunmul.com/index.php/diglosia/article/view/30

\title{
RESISTANSI TERHADAP OBJECTIFICATIONDALAM NOVEL MASH-UP PRIDE AND PREJUDICE AND ZOMBIES DARI NOVEL KLASIK PRIDE AND PREJUDICE
}

\section{The Resistance towards Objectification in Mash-up Novel Pride and Prejudice and Zombies from Classic Novel Pride and Prejudice}

\author{
Cindy Belinda Ramadhanty \\ Magister Kajian Sastra dan Budaya, Fakultas Ilmu Budaya \\ Universitas Airlangga, Surabaya \\ Pos-el Korespondensi: bee_victory@yahoo.co.uk
}

\begin{abstract}
This study deals with objectification, especially towards Elizabeth Bennet (Liz:ay), in the classic novel Pride and Prejudice (1813) and the mash-up novel Pride and Prejudice and Zombies (2009) which were written by Jane Austen and Seth Grahame-Smith. This study aims to examine how the resistance towards objectification is pictured in the mash-up novel Pride and Prejudice and Zombies using Nussbaum's theory of objectification. As a comparative study, there are some things that will be compared in this study, such as the different time period when both novels were first published, the way the authors pictured objectification, and the addition of zombie in the mash-up novel Pride and Prejudice and Zombies. This study uses qualitative method with comparative literature as the approach. The result of this study concludes that Lizizy is objectified by Mr. Collins in terms of instrumentality, fungibility, ownership, and denial of subjectivity. The addition of zombie in the mash-up novel Pride and Prejudice and Zombies implies as if there is a resistance towards objectification, with Liz:y having the skills of a warrior, while in fact the objectification is real as experienced by Lizay. In the perspective of comparative literature, mash-up novel Pride and Prejudice and Zombies tends to have ambivalence even though it is published in postmodern era. On one hand, Lizay is able to defend herself from zombie, on the other hand, she still falls victim to the objectification done by Mr. Collins. In other words, the resistance towards objectification in the mash-up novel Pride and Prejudice and Zombies is not able to protect Liz氵y from the objectification done by Mr. Collins.
\end{abstract}

Keywords: feminism, mash-up novel, objectification, patriarchy, comparative literature

\begin{abstract}
Abstrak: Penelitian ini berhubungan dengan objectification, khususnya terhadap Elizabeth Bennet (Lizzy), dalam novel klasik Pride and Prejudice (1813) dan novel mash-up Pride and Prejudice and Zombies (2009) yang ditulis oleh Jane Austen dan Seth Grahame-Smith. Penelitian ini bertujuan untuk meneliti bagaimana resistansi terhadap objectification digambarkan di novel mash-up Pride and Prejudice and Zombies dengan menggunakan teori objektifikasi dari Nussbaum. Sebagai sebuah kajian sastra bandingan, terdapat beberapa hal yang dibandingkan dalam penelitian ini, seperti perbedaan zaman ketika kedua novel tersebut pertama kali diterbitkan, faktor penulis dalam menggambarkan objectification tersebut, serta penambahan unsur zombie pada novel mash-up Pride and Prejudice and Zombies. Penelitian ini menggunakan pendekatan kualitatif dengan sastra bandingan sebagai cara bacanya. Hasil penelitian ini mengemukakan bahwa Lizzy diperlakukan sebagai sebuah objek oleh Mr. Collins dalam hal instrumentality, fungibility, ownership, dan denial of subjectivity. Penambahan unsur modernitas seperti adanya zombie dalam novel mash-up Pride and Prejudice and Zombies seolah memunculkan resistansi terhadap objectification, dengan diberikannya kemampuan bela diri pada Lizzy, namun di sisi lain, objectification tersebut masih nyata adanya seperti yang dialami oleh Lizzy. Dalam perspektif sastra bandingan, novel mash-up Pride and Prejudice and Zombies cenderung memiliki ambivalensi meskipun diterbitkan pada era posmodern. Di satu sisi, penambahan unsur modernitas tersebut membuat Lizzy mampu mempertahankan dirinya sendiri dari serangan zombie, namun di
\end{abstract}


sisi lain ia masih tetap menjadi korban objectification Mr. Collins. Dengan kata lain, resistansi terhadap objectification dalam novel mash-up Pride and Prejudice and Zombies belum mampu melindungi Lizzy dari objectification yang dilakukan oleh Mr. Collins.

Kata kunci: feminisme, novel mash-up, objectification, patriarki, sastra bandingan

\section{A. PENDAHULUAN}

Dalam sebuah masyarakat patriarki, perempuan selalu dianggap 'inferior' jika dibandingkan dengan laki-laki. Perempuan adalah sosok yang tidak mempunyai kehendak karena laki-laki bebas untuk 'menggunakan' perempuan kapan pun dan di manapun laki-laki mau. Hal ini disebabkan oleh fakta bahwa perempuan biasanya dikuasai oleh lakilaki. Banyak perempuan yang diperlakukan sebagai sebuah objek oleh lawan jenisnya. Dalam perspektif feminis, fenomena ini disebut sebagai objectification. Kebanyakan contoh dari objectification terjadi pada ranah seksual, ranah di mana perempuan diperlakukan hanya sebagai sebuah objek untuk memuaskan nafsu laki-laki.

Penelitian ini menggunakan novel klasik Pride and Prejudice (1813) dan novel mash-up Pride and Prejudice and Zombies (2009) yang ditulis oleh Jane Austen dan Seth Grahame-Smith sebagai contoh karya sastra yang melihat perempuan sebagai objek di luar ranah seksual. Pride and Prejudice adalah sebuah novel klasik dari Inggris yang dianggap sebagai sebuah sastra canon dalam dunia sastra dunia, yang mana 'warisan' dari novel ini dapat ditemukan dalam berbagai macam bentuk dan jenis karya, seperti novel mash-up Pride and Prejudice and Zombies sebagai contohnya. Pride and Prejudice and Zombies dianggap sebagai sebuah pendahulu novel mash-up karena "banyak karya sastra lain yang muncul dalam bentuk sastra canon/subgenre monster mash-up sejak diterbitkan pertama kali pada tahun 2009, menambahkan elemen kontemporer dan posmodern seperti zombie, vampire, werewolf, monster laut, mummy, dan android pada sastra canon aslinya. Dengan hampir satu juta buku terjual dalam waktu kurang dari enam bulan sejak penjualan pertamanya, novel mash-up ini berada lebih dari lima puluh minggu pada daftar 'Penjualan Terbaik' The New York Times, membuat sebuah trend dalam subgenre mash-up yang baru ini" (Chretien, 2011, p. 8).

Pride and Prejudice bercerita tentang seorang perempuan bernama Elizabeth Bennet (Lizzy), yang tertarik pada Mr. Fitzwilliam Darcy ketika bertemu dengannya untuk pertama kali di sebuah pesta dansa yang diadakan di Netherfield. Pada awalnya, Mr. Darcy digambarkan sebagai seorang laki-laki yang angkuh. Seiring berjalannya waktu, Lizzy dan Mr. Darcy dapat menghilangkan prasangka mereka terhadap satu sama lain dan akhirnya menjadi sepasang kekasih. Novel mash-up Pride and Prejudice and Zombies juga menceritakan hal yang sama seperti novel klasik Pride and Prejudice, namun ada penambahan unsur modernitas zombie di dalamnya, serta diberikannya kemampuan sebagai warrior pada anak-anak perempuan keluarga Bennet dalam novel mash-up tersebut.

Pride and Prejudice and Zombies menambahkan elemen kekerasan pada cerita klasik aslinya, membuktikan bahwa novel tersebut adalah sebuah contoh adaptasi feminis kontemporer dari karya klasik Austen. Kekerasan dalam novel tersebut mencerminkan keprihatinan perempuan pada era postmodern saat ini di mana mereka lebih mandiri dan tidak bergantung lagi pada laki-laki dalam membela diri. Pada novel tersebut, hal ini ditunjukkan dengan bagimana para anak perempuan keluarga Bennet mampu untuk melindungi diri mereka sendiri dari serangan zombie dengan menggunakan kemampuan warrior mereka. Hal ini menjadi validasi dalam memilih objek 
material penelitian ini, yaitu novel klasik Pride and Prejudice dan novel mash-up Pride and Prejudice and Zombies, sebagai dua objek yang akan dibandingkan menurut faktor zamannya, faktor penulisnya, serta faktor penambahan elemen kontemporer yang ditambahkan oleh Seth GrahameSmith.

Dalam menganalisis permasalahan tentang objectification, penelitian ini menggunakan beberapa konsep yang dikemukakan oleh Martha Nussbaum dalam artikel jurnalnya yang berjudul Objectification (1995). Nussbaum mengatakan bahwa seseorang terkena objectification ketika ia dilihat dan/atau diperlakukan dalam satu atau lebih dari tujuh ciri yang berhubungan dengan pemikiran tentang memperlakukan seseorang sebagai objek seperti berikut: (1) Instrumentality: memperlakukan seseorang sebagai benda untuk kepentingan si objectifier; (2) Denial of autonomy: memperlakukan seseorang seperti benda yang tidak mempunyai kebebasan dan kemauan diri; (3) Inertness: memperlakukan seseorang seperti benda yang selalu bergantung pada orang lain, bahkan mungkin saat beraktivitas; (4) Fungibility: memperlakukan seseorang seperti benda yang dapat digantikan fungsinya dengan benda lain; (5) Violability: memperlakukan seseorang seperti benda yang tidak mempunyai integritas; (6) Ownership: memperlakukan seseorang seperti sesuatu yang dimiliki oleh orang lain (dapat diperjualbelikan); dan (7) Denial of subjectivity: memperlakukan seseorang yang pengalaman serta perasaannya (jika ada) tidak perlu diperhitungkan (Nussbaum, 1995, p. 257).

Untuk mendukung analisis penelitian ini, terdapat beberapa penelitian terdahulu yang mengaplikasikan teori objectification pada karya sastra lainnya. Penelitian terdahulu tersebut termasuk objectification terhadap tokoh protagonis utama, Belinda, dalam
Rape of the Lock karya Pope (Ferguson, 1992); bagaimana disabilitas memainkan peran penting tentang objectification dalam Nausicaa karya James Joyce (Bednarska, 2011); dan seksualitas maskulin dan objectification dalam perspektif Steinbeck (Gladstein, 2004). Kesamaan dari beberapa penelitian terdahulu tersebut ialah dalam setiap karya sastra, perempuan diperlakukan sebagai sebuah objek oleh lawan jenisnya, meskipun mereka penyandang disabilitas. Masyarakat patriarki yang menjadi latar belakang dari beberapa penelitian terdahulu tersebut menunjukkan bahwa perempuan memang benar-benar 'inferior' jika dibandingkan dengan lakilaki. Perempuan tidak lagi dianggap sebagai seorang manusia ketika mengalami objectification. Meskipun begitu, salah satu dari penelitian terdahulu tersebut mengungkapkan sesuatu yang menarik yang memberikan wawasan baru dalam melihat objectification dari perspektif lainnya, yaitu objectification tidak hanya melemahkan, namun juga memberikan kekuatan.

Rebecca Ferguson dalam artikelnya yang berjudul 'Quick as her Eyes, and as unfix'd as those': Objectification and Seeing in Pope's Rape of the Lock yang ditulis pada tahun 1992, meneliti objectification yang dialami oleh tokoh protagonis perempuan dari puisi tersebut yang bernama Belinda. Meskipun begitu, Belinda bukanlah sekedar objek dalam puisi tersebut, tapi sekaligus bertindak sebagai subjek. Ferguson mengungkapkan bahwa di dalam puisi tersebut, Belinda melihat dirinya sebagai pusat perhatian sang penyair, yang menunjukkan bahwa dirinya adalah orang yang dapat menguasai sang penyair tersebut. Artikel ini menunjukkan bahwa Belinda tidak hanya lemah, namun mempunyai kekuatan. Memang, ia diperlakukan sebagai sebuah objek oleh sang penyair, namun di sisi lain, ia adalah seseorang yang mempunyai kekuatan untuk menguasai sang penyair tersebut. 
Terlepas dari ketiga penelitian sebelumnya, belum ada penelitian/kajian formal tentang objectification dalam Pride and Prejudice dan Pride and Prejudice and Zombies karya Jane Austen dan Seth Grahame-Smith sejauh ini.

Selain itu, terdapat beberapa penelitian terdahulu yang menggunakan objek yang sama namun menggunakan teori yang berbeda. Penelitian terdahulu tersebut meliputi permasalahan tentang sopan santun, kekerasan, dan adaptasi kontemporer dari karya-karya Jane Austen (Chretien, 2011); ketepatan dalam membangkitkan kembali karya-karya Jane Austen (Toth, 2010); dan meraih Austen dan kemungkinan adaptasi feminis dari Pride and Prejudice and Zombies (Jasper, 2016).

Kesamaan dari penelitian terdahulu tersebut ialah semuanya meneliti novel tersebut melalui sifat ketemporerannya dan bagaimana hal tersebut diterima oleh pembaca di seluruh dunia, khususnya Janeites, yaitu fans Jane Austen sendiri. Elemen rombie yang ditambahkan oleh Seth Grahame-Smith tentunya membuat novel aslinya tidak lagi termasuk ke dalam sastra "klasik", melainkan pada sastra mash-up, yaitu sebuah subgenre dalam sastra kontemporer yang biasanya menambahkan elemen posmodern populer pada sastra conon yang telah ada sebelumnya. Elisabeth Chretien, dalam tesisnya yang berjudul "Gentility and Canon under Seige: Pride and Prejudice and Zombies, Violence, and Contemporary Adaptations of Jane Austen" berargumen bahwa "kekerasan dalam novel tersebut membuat ruang untuk persamaan gender yang lebih baik pada cerita dalam novel tersebut dan mencerminkan keprihatinan perempuan pada era postmodern saat ini" (Chretien, 2011, p. 40). Hal ini berarti bahwa meskipun cerita aslinya dianggap sebagai sastra "klasik", namun cerita tersebut masih tetap relevan dan dapat dipahami oleh masyarakat yang hidup di era posmodern. Terlepas dari ketiga penelitian sebelumnya, belum ada penelitian/kajian formal yang menggunakan Pride and Prejudice dan Pride and Prejudice and Zombies karya Jane Austen dan Seth Grahame-Smith yang membahas tentang objectification sejauh ini.

Berdasarkan penjelasan tersebut, penelitian ini bertujuan untuk meneliti bagaimana resistansi terhadap objectification digambarkan di novel mash-up Pride and Prejudice and Zombies dengan menggunakan teori objektifikasi dari Nussbaum. Sebagai sebuah kajian sastra bandingan, terdapat beberapa hal yang dibandingkan dalam penelitian ini, seperti perbedaan zaman ketika kedua novel tersebut pertama kali diterbitkan, faktor penulis dalam menggambarkan objectification tersebut, serta penambahan unsur zombie pada novel mash-up Pride and Prejudice and Zombies.

\section{B. METODE}

Penelitian ini menggunakan pendekatan kualitatif dalam menginterpretasi objek penelitian, yaitu novel klasik Pride and Prejudice dan novel mash-up Pride and Prejudice and Zombies. Untuk mendapatkan pemahaman yang lebih mendalam antara objek penelitian, teori yang dipakai, serta topik yang dibahas, lensa teoretis yang menggunakan pendekatan feminis adalah bagian penting dalam penelitian ini dalam meneliti permasalahan tentang objectification.

Terdapat dua jenis sumber data yang digunakan dalam penelitian ini, yaitu sumber data primer dan sumber data sekunder. Novel klasik Pride and Prejudice dan novel mash-up Pride and Prejudice and Zombies digunakan sebagai sumber data primer dalam penelitian ini. Terdapat beberapa adegan dalam kedua novel tersebut yang berhubungan dengan permasalahan tentang objectification. Adegan-adegan tersebut kemudian menjadi sumber primer dalam penelitian ini, begitu pula dengan aspek naratif yang digunakan sebagai informasi utama untuk 
mendukung analisis penelitian ini. Untuk sumber sekunder, penelitian ini menggunakan beberapa data yang terlegitimasi dari beberapa sumber seperti buku, tesis, jurnal, dan beberapa artikel dari website yang berhubungan dengan permasalahan tentang objectification.

Dalam penelitian ini, data tersebut dikumpulkan dari semua halaman dalam kedua novel tersebut. Pertama-tama, dilakukan pembacaan secara mendalam (close reading) terhadap keselurahan teks dengan membaca seluruh halaman yang ada dalam kedua novel tersebut. Kemudian, memilih halaman yang menunjukkan bagaimana tokoh laki-laki memperlakukan tokoh perempuan yang berhubungan dengan permasalahan tentang objectification. Setelah menemukan halaman tersebut, menandai halaman yang telah dipilih yang meliputi cerita atau aksi yang berhubungan dengan permasalahan objectification yang bertindak sebagai data primer dalam penelitian ini. Setelah memilih dan memilah halaman yang telah dipilih, kemudian meneliti dialog untuk dianalisis berdasarkan aspek naratifnya, yang meliputi cerita dan elemen formal dari kedua novel tersebut.

Untuk teknik analisis data, dilakukan analisis terhadap kedua novel tersebut melalui aspek naratifnya, yang berfokus pada cerita dalam kedua novel tersebut, serta elemen formalnya. Empat ciri dari teori objectification yang ditemukan oleh Nussbaum juga digunakan dalam penelitian ini untuk mendukung fokus dari pertanyaan utama tentang permasalahan objectification. Empat ciri tersebut ialah instrumentality, fungibility, ownership, dan denial of subjectivity. Sebagai sebuah kajian sastra bandingan, terdapat beberapa hal yang dibandingkan dalam penelitian ini, seperti perbedaan zaman ketika kedua novel tersebut pertama kali diterbitkan, faktor penulis dalam menggambarkan objectification tersebut, serta penambahan unsur rombie pada novel mash-up Pride and Prejudice and Zombies.

\section{PEMBAHASAN}

Sebagai sebuah kajian sastra bandingan, perlu diketahui terlebih dahulu persamaan dan perbedaan yang terdapat dalam novel klasik Pride and Prejudice dan novel mash-up Pride and Prejudice and Zombies. Dalam tabel 1, dapat dilihat beberapa persamaan dan perbedaan yang terdapat dalam kedua novel tersebut. Selain itu, perlu diperhatikan pula faktor perbedaan zaman ketika kedua novel tersebut pertama kali diterbitkan, faktor penulis dalam menggambarkan objectification tersebut, serta penambahan unsur zombie pada novel mash-up Pride and Prejudice and Zombies.

Perbedaan zaman ketika novel klasik Pride and Prejudice dan novel mash-up Pride and Prejudice and Zombies diterbitkan membuat penelitian ini dapat disebut sebagai penelitian sastra bandingan diakronik. Meskipun terdapat jarak waktu yang sangat lama dari diterbitkannya novel klasik Pride and Prejudice dengan novel mash-up Pride and Prejudice and Zombies untuk pertama kali, namun permasalahan mengenai objectification serta tema tentang harga diri dan prasangka yang terdapat dalam kedua novel tersebut masih sangat relevan dengan kehidupan bermasyarakat dalam era posmodern ini.

Jenis kelamin penulis kedua novel tersebut yang berbeda sangat mempengaruhi bagaimana objectification digambarkan dalam kedua novel tersebut. Jane Austen, sebagai seorang perempuan yang tidak pernah menikah semasa hidupnya, menggambarkan tokoh perempuan yang cerdas, pandai berargumen, serta mempunyai wawasan yang luas, meskipun begitu tokoh perempuan tersebut tetap mengalami objectification pada akhirnya (secara verbal dengan menggunakan bahasa yang tidak terlalu eksplisit, namun juga tidak terlalu 
implisit). Sedangkan Seth GrahameSmith, sebagai seorang penulis naskah berkebangsaan Amerika Serikat, memadukan unsur zombie ke dalam novel mash-up yang ditulisnya karena zombie merupakan salah satu hal yang paling diminati dalam masyarakat era posmodern seperti saat ini. Ia juga memberikan unsur bela diri sebagai 'resistansi' terhadap serangan zombie yang ada, namun hal tersebut tampaknya belum mampu untuk melindungi anakanak perempuan keluarga Bennet dari objectification (khususnya yang dialami oleh Lizzy sebagai tokoh utama perempuan dalam kedua novel tersebut).

Tabel 1. Persamaan dan Perbedaan Novel Klasik Pride and Prejudice dan Novel Mash-up Pride and Prejudice and Zombies

\begin{tabular}{ccc}
\hline & & \multicolumn{2}{c}{ Perbedaan } \\
\cline { 2 - 3 } No. $\quad$ Persamaan & Pride and Prejudice & Pride and Prejudice and \\
Zombies
\end{tabular}

1. Dalam kedua novel, tokoh utama Tidak ada unsur zombie perempuan sama-sama mengalami objectification

2. Tema dalam kedua novel tersebut sama-sama tentang harga diri dan prasangka

3. Dalam kedua novel, Mr. Darcy digambarkan terpesona dengan Lizzy

4. Dalam kedua novel, Jane digambarkan kehujanan saat pergi ke rumah Mr. Bingley

5. Dalam kedua novel, Mr. Darcy digambarkan memiliki tipe perempuan ideal

6. Dalam kedua novel, terdapat pesta yang berlangsung di tempat Mr. Bingley

7. Dalam kedua novel, Charlotte digambarkan menikah dengan Mr. Collins

8. Dalam kedua novel, Lizzy digambarkan bertemu dengan Lady Catherine

9. Dalam kedua novel, Mr. Darcy digambarkan melamar Lizzy

10. Dalam kedua novel, anak-anak perempuan keluarga Bennet digambarkan sedang berkumpul bersama

11. Dalam kedua novel, Lizzy digambarkan sedang bersama dengan Mr. dan Mrs. Gardiner

Tidak ada unsur bela diri
Mr. Darcy terpesona akan mata indah Lizzy (p. 25)

Jane kehujanan saat pergi ke rumah Mr. Bingley (p. 27)

Perempuan ideal menurut Mr. Darcy (domesticated housewife) (p. 35)

Mary bermain piano di pesta Mr. Bingley (p. 87)

Charlotte menikah dengan Mr. Collins karena usianya menginjak 27 tahun (p. 124)

Lizzy tidak ditantang oleh Lady Catherine untuk bertarung (p. 143)

Mr. Darcy melamar Lizzy untuk pertama kali, ditolak oleh Lizzy secara verbal (p. 163)

Anak-anak perempuan keluarga Bennet bersantai bersama (p. 194)

Lizzy serta Mr. dan Mrs. Gardiner berkeliling di sekitar kediaman Mr. Darcy (p. 210)
Ada unsur bela diri

Ada unsur zombie

Mr. Darcy terpesona akan kemampuan warrior Lizzy (p. 15)

Jane kehujanan dan bertemu zombie saat pergi ke rumah Mr. Bingley (p. 29)

Perempuan ideal menurut Mr. Darcy (domesticated female warrior) (p. 34)

Ada serangan rombie di pesta Mr. Bingley (p. 81)

Charlotte menikah dengan Mr. Collins karena digigit oleh zombie (p. 111)

Lizzy ditantang oleh Lady Chaterine untuk bertarung ( $p$. 131)

Mr. Darcy melamar Lizzy untuk pertama kali, ditolak oleh Lizzy dengan tindakan (p. 150)

Anak-anak perempuan keluarga Bennet bermain Kiss Me Deer yang diciptakan oleh Mr. Bennet (p. 150)

Terdapat serangan zombie ketika Mr. dan Mrs. Gardiner berkeliling di sekitar 
12. Dalam kedua novel, Lady Catherine digambarkan bertemu dengan Lizzy

13. Dalam kedua novel, Mr. Collins digambarkan mencintai Charlotte (secara implisit)

14. Dalam kedua novel, Mr. Darcy dan Lizzy digambarkan menjadi sepasang kekasih
Lady Catherine menanyakan hubungan Lizzy dengan Mr. Darcy (p. 299)

Mr. Collins dan Charlotte hidup bahagia setelah menikah (p. 305)

Mr. Darcy dan Lizzy akhirnya bersama (p. 311) kediaman Mr. Darcy (p. 183)

Lady Catherine menanyakan hubungan Lizzy dengan Mr. Darcy dan menantangnya untuk berduel (p. 200)

Mr. Collins bunuh diri setelah kematian Charlotte (p. 297)

Mr. Darcy dan Lizzy akhirnya bersama menjadi warrior yang melindungi masyarakat dari zombie (p. 303)
Seperti yang terdapat dalam tabel tersebut, persamaan yang ada pada kedua novel tersebut adalah yang pertama tokoh utama perempuan sama-sama mengalami objectification, dan yang kedua tema yang diangkat dalam kedua novel tersebut sama-sama tentang harga diri dan prasangka. Tokoh utama perempuan dalam kedua novel tersebut sama-sama mengalami objectification dalam hal instrumentality, fungibility, ownership, dan denial of subjectivity. Berikut beberapa kutipan yang menunjukkan bahwa tokoh utama perempuan dalam kedua novel tersebut sama-sama mengalami objectification:

\section{Instrumentality}

Pada novel klasik Pride and Prejudice dan novel mash-up Pride and Prejudice and Zombies, Elizabeth Bennet (Lizzy) diperlakukan sebagai sebuah objek oleh Mr. Collins, sepupu Mr. Bennet. Mr. Collins adalah seorang pastor berusia 25 tahun yang ayahnya mempunyai hubungan yang kurang baik dengan Mr. Bennet. Karena Mr. Bennet mempunyai lima anak perempuan dan tidak mempunyai anak laki-laki, Mr. Collins akan menjadi pewaris Longbourn ketika Mr. Bennet meninggal karena ia adalah keluarga laki-laki terdekat Mr. Bennet.

Pada suatu hari, Mr. Bennet memberi tahu istrinya dan kelima anaknya bahwa Mr. Collins akan mengunjungi Longbourn. Ternyata kunjungannya ke Longbourn sebenarnya untuk mencari seorang istri. Hal ini dibuktikan oleh dialog yang diucapkan oleh Mr. Collins kepada Lizzy dalam novel klasik Pride and Prejudice seperti yang telihat pada kutipan di bawah ini.

\begin{abstract}
"Believe me, my dear Miss Elizabeth, that your modesty, so far from doing you any disservice, rather adds to your other perfections. You would have been less amiable in my eyes had there not been this little unwillingness; but allow me to assure you that I have your respected mother's permission for this address. You can hardly doubt the purport of my discourse; however your natural delicacy may lead you to dissemble; my attentions have been too marked to be mistaken. Almost as soon as I entered the house I singled you out as the companion of my future life. But before I am run away with by my feelings on this subject, perbaps it will be advisable for me to state my reasons for marrying - and moreover for coming into Herffordshire with the design of selecting a wife, as I certainly did" (Austen, 1813, p. 90).
\end{abstract}

Pada novel mash-up Pride and Prejudice and Zombies, Mr. Collins mengatakan hal yang serupa kepada Lizzy, namun terdapat sedikit perbedaan seperti yang terlihat dalam kutipan di bawah ini.

"Believe me, my dear Miss Elizabeth, that your modesty adds to your other perfections. You would have been less amiable in my eyes had there not been this little unwillingness; but allow me to assure you that I have your respected mother's permission for this address. You can hardly doubt the purport of my 
discourse, for however preoccupied you might be with hastening the Devil's retreat_for which I earnestly applaud you - my attentions have been too marked to be mistaken. Almost as soon as I entered the house I singled you out as the companion of my future life. But before I am run away with by my feelings on this subject, perhaps it would be advisable for me to state my reasons for marrying - and, moreover, for coming into Hertfordshire with the design of selecting a wife, as I certainly did" (Austen \& Grahame-Smith, 2009, p. 84).

Lebih lanjut, Mr. Collins malah meminta Lizzy untuk 'pensiun' sebagai seorang warrior, seperti yang terlihat pada dialog yang diucapkan Mr. Collins ke Lizzy pada kutipan di bawah ini.

"...You will find her powers of combat beyond anything I can describe; and your own talents in slaying the stricken, I think, must be acceptable to her, though naturally, I will require you to retire them as part of your marital submission" (Austen \& Grahame-Smith, 2009, p. 85).

Pada novel klasik Pride and Prejudice karena tidak ada unsur zombie dalam novel ini, Mr. Collins digambarkan menyampaikan pemikirannya tentang menikahi Lizzy di masa depan, seperti yang terlihat dalam kutipan di bawah ini.

"...Y You will find her manners beyond anything I can describe; and your wit and vivacity I think must be acceptable to her, especially when tempered with the silence and respect which her rank will inevitably excite. Thus, much for my general intention in favour of matrimony; it remains to be told why my views were directed to Longbourn instead of my own neighbourbood, where $I$ assure you there are many amiable young women. But the fact is, that being, as I am, to inherit this estate after the death of your honoured father, (who, however, may live many years longer,) I could not satisfy myself without resolving to choose a wife from among his daughters, that the loss to them might be as little as possible, when the melancholy event takes place - which, however, as I have already said, may not be for several years. This has been my motive, my fair cousin, and I flatter myself it will not sink me into your esteem.
And now nothing remains for me but to assure you in the most animated language of the violence of my affection. To fortune $I$ am perfectly indifferent, and shall make no demand of that nature on your father, since I am well aware that it could not be complied with; and that one thousand pounds in the 4 per cents. which will not be yours till after your mother's decease, is all that you may ever be entitled to. On that head, therefore, I shall be uniformly silent; and you may assure yourself that no ungenerous reproach shall ever pass my lips when we are married" (Austen, 1813, p. 91).

Cara Mr. Collins memperlakukan Lizzy dalam kedua novel tersebut dapat dikategorikan sebagai instrumentality, yang, menurut Nussbaum (1995, p. 257), berarti memperlakukan seseorang sebagai sebuah benda untuk kepentingan si objectifier. Dalam hal ini, Mr. Collins adalah objectifier dan Lizzy adalah yang mengalami objectification, artinya Mr. Collins adalah orang yang melakukan objectification terhadap Lizzy. Lizzy, di sisi lain, diperlakukan sebagai sebuah objek oleh Mr. Collins. Mr. Collins hanya membutuhkan Lizzy sebagai calon istrinya yang potensial karena ia ingin mencapai tujuannya mencari seorang istri. Terlebih lagi, Mr. Collins menjadi lebih 'superior' karena ia memiliki kuasa atas Lizzy karena para perempuan muda pada era Regency diharapkan dapat menikah pada usia dini. Seperti yang dikatakan oleh Betts (2015), pada era Regency, "sebuah pernikahan yang baik dengan seorang laki-laki dengan pendapatan yang bagus adalah hal yang penting bagi seorang perempuan karena ia tidak mempunyai sumber sokongan dana lainnya". Hal ini membuat Lizzy menjadi yang lebih 'inferior' karena ia harus menerima lamaran Mr. Collins apapun yang terjadi karena jika tidak, ia tidak akan mendapatkan seorang suami yang akan mengurusnya setelah ayahnya meninggal.

Melihat pada aspek naratif tersebut, dapat diasumsikan bahwa Mr. Collins 
melakukan objectification terhadap Lizzy dalam hal ia hanya membutuhkan Lizzy sebagai calon istrinya yang potensial karena ia perlu menikahi seorang 'perempuan'. Tidak terlalu penting bagi Mr. Collins apakah 'pihak lain' mencintainya atau tidak karena yang ia butuhkan hanya seorang istri. Cinta bukanlah sesuatu yang penting dari sebuah pernikahan. Mr. Collins tidak mempertimbangkan apakah Lizzy mencintainya atau tidak, akan tetapi ia tetap melamar Lizzy begitu saja seolaholah Lizzy akan menerima lamarannya dan melakukan apa yang diperintahnya; sampai pada tingkat ia akan 'pensiun' menjadi seorang warrior dan akan sepenuhnya menjadi seorang ibu rumah tangga. Mr. Collins di sini benar-benar memperlakukan Lizzy sebagai sebuah benda untuk memenuhi tujuannya, yaitu untuk menikah.

\section{Fungibility}

Seperti yang telah dijelaskan sebelumnya, dalam novel klasik Pride and Prejudice dan novel mash-up Pride and Prejudice and Zombies, Lizzy diperlakukan sebagai sebuah objek oleh Mr. Collins. Seiring dengan berjalannya cerita, terungkaplah bahwa Mr. Collins juga melakukan objectification pada tokoh perempuan lainnya dengan cara yang mirip seperti ketika Lizzy menjadi korban objectification oleh Mr. Collins. Tokoh perempuan tersebut tidak lain adalah sahabat Lizzy, Charlotte Lucas. Charlotte mengaku pada Lizzy bahwa ia menerima lamaran Mr. Collins karena ia hanya menginginkan tempat tinggal yang layak di masa depan. Hal tersebut dapat dilihat dalam novel klasik Pride and Prejudice pada kutipan di bawah ini.

\footnotetext{
"I see what you are feeling," replied Charlotte, "you must be surprised, very much surprised, so lately as Mr Collins was wishing to marry you. But when you have had time to think it all over, I bope you will be satisfied with what I have done. I am not romantic you know. I
}

never was. I ask only a comfortable home; and considering $\mathrm{Mr}$ Collin's character, connections, and situation in life, I am convinced that my chance of happiness with him is as fair, as most people can boast on entering the marriage state" (Austen, 1813, p. 108).

Sedikit berbeda dengan yang tertulis dalam kutipan tersebut, dalam novel mash-up Pride and Prejudice and Zombies, Charlotte mengaku pada Lizzy bahwa ia menerima lamaran Mr. Collins karena ia telah terkena gigitan rombie. Hal tersebut dapat dilihat dalam kutipan di bawah ini.

\section{"I see what you are feeling," replied Charlotte. "You must be surprised, very much surprised- so lately as Mr. Collins was wishing to marry you. But when you have had time to think it over, I hope you will be satisfied with what I have done. I am not romantic, you know; I never was. I ask only a comfortable home; and considering Mr. Collin's character, connection, and situation in life, I am convinced that my chance of happiness with him is as fair as most people can boast on entering the marriage state—especially since, ob! Elizabeth, I beg you will not be angry with me or cut me down where I stand! But Elizabeth, I can have no secrets from you -I have been stricken." (Austen \& Grahame-Smith, 2009, p. 99).}

Berdasarkan kutipan-kutipan tersebut, dapat diketahui bahwa Mr. Collins juga melamar Charlotte dengan tujuan untuk mencari seorang istri. Dapat diasumsikan bahwa Mr. Collins melakukan objectification baik terhadap Lizzy maupun Charlotte dalam hal ia hanya membutuhkan mereka sebagai calon istrinya yang potensial karena ia perlu menikahi seorang 'perempuan'. Tidak terlalu penting bagi Mr. Collins apakah 'pihak lain' mencintainya atau tidak karena yang ia butuhkan hanya seorang istri. Cinta bukanlah sesuatu yang penting dari sebuah pernikahan.

Mr. Collins di sini memperlakukan Lizzy dan Charlotte seperti benda yang dapat digantikan fungsinya dengan benda lain, atau yang disebut juga sebagai 
fungibility, seperti yang dikemukakan oleh Nussbaum (1995, p. 257), yang menunjukkan bahwa Mr. Collins, setelah ditolak oleh Lizzy, ia kemudian berpindah ke Charlotte dan mencoba untuk melamarnya dengan harapan ia akan menerima lamarannya dan ia akan mendapatkan istri yang sah. Bagi Mr. Collins, calon istrinya kelak tidak harus Lizzy atau Charlotte secara khusus; selama calon istrinya masih perempuan, maka siapapun tidak masalah. Sama seperti seseorang yang sedang membutuhkan pulpen, tidak penting baginya untuk menggunakan pulpen khusus, asalkan pulpen tersebut dapat digunakan untuk menulis, maka pulpen tersebut akan digunakannya. Mr. Collins pada dasarnya hanya perlu seorang perempuan untuk menjadi istrinya, tanpa kriteria tertentu dan cinta (romansa) ataupun hal lainnya terhadap calon istrinya kelak.

\section{Ownership}

Dalam novel klasik Pride and Prejudice dan novel mash-up Pride and Prejudice and Zombies, Lizzy diperlakukan sebagai sesuatu yang dapat diperdagangkan oleh ibunya sendiri, Mrs. Bennet, dan Mr. Collins. Seperti yang terlihat dalam dialog yang diucapkan Mrs. Bennet kepada Mr. Collins setelah Lizzy menolaknya dalam novel klasik Pride and Prejudice berikut ini, "'But depend upon it, Mr Collins,' she added, 'that Lizay shall be brought to reason. I will speak to her about it myself directly. She is a very headstrong foolish girl, and does not know her own interest; but I will make her know it." (Austen, 1813, p. 96). Tidak banyak berbeda dengan kutipan tersebut, dalam novel mash-up Pride and Prejudice and Zombies, Mrs. Bennet mengutarakan hal yang sama kepada Mr. Collins seperti yang terlihat pada kutipan berikut ini, "But, depend upon it, Mr. Collins," she added, "that Lizay shall be brought to reason. I will speak to her about it directly. She is a very headstrong, foolish girl, and does not know her own interest-but I will make ber know it." (Austen \& Grahame-Smith, 2009, p. 87).

Mrs. Bennet berbicara seolah-olah Lizzy adalah sebuah produk yang dapat diperjualbelikan melalui sebuah kesepakatan. Memperlakukan seseorang seperti sesuatu yang dimiliki oleh orang lain (dapat diperjualbelikan), disebut sebagai ownership oleh Nussbaum (1995, p. 257). Mrs. Bennet di sini bertindak sebagai agen patriarki, yang berarti ia mempunyai peran untuk menikahkan kelima anak perempuannya pada laki-laki yang bermartabat, tidak terkecuali Lizzy. Seperti yang diungkapkan oleh sang narator pada bagian awal novel klasik Pride and Prejudice, "The business of her life was to get her daughters married; its solace was visiting and news" (Austen, 1813, p. 4). Dalam novel mash-up Pride and Prejudice and Zombies, kalimat tersebut menjadi sedikit berbeda, "The business of $M r$. Bennett's life was to keep his daughters alive. The business of Mrs. Bennett's was to get them married' (Austen \& Grahame-Smith, 2009, p. 9). Dapat dilihat di sini bahwa Mrs. Bennet adalah 'penjual' dan Mr. Collins adalah 'pembeli' karena mereka berdua memperlakukan Lizzy seperti sesuatu yang dapat diperjualbelikan.

Melihat aspek naratif tersebut, dapat diasumsikan bahwa Mrs. Bennet adalah seseorang yang lebih 'superior' karena ia adalah ibu kandung Lizzy, ia mempunyai kuasa yang absolut terhadap Lizzy. Mrs. Bennet sangat percaya diri bahwa sekali ia menasehati Lizzy, Lizzy akan langsung menerima lamaran Mr. Collins. Hal ini dapat dilihat secara tidak langsung bahwa Mrs. Bennet mempunyai suatu kuasa atas Lizzy yang bertindak sebagai keuntungan untuknya dalam meyakinkan Mr. Collins bahwa Lizzy akan menerima lamarannya. Dalam hal ini, Mrs. Bennet adalah objectifier dan Lizzy adalah yang mengalami objectification karena Lizzy tidak lagi dilihat sebagai salah satu anak perempuannya, seorang manusia, melainkan sebagai sebagai sesuatu yang dapat 
diperjualbelikan pada orang lain; yang mana dalam hal ini, Lizzy ‘diperdagangkan' pada Mr. Collins.

\section{Denial of Subjectivity}

Di antara semua tokoh perempuan dalam novel klasik Pride and Prejudice dan novel mash-up Pride and Prejudice and Zombies, Lizzy adalah satu-satunya tokoh perempuan yang terlihat menonjol dalam mengalami ciri ini. Seperti yang diungkapkan Lizzy ketika ia menolak lamaran Mr. Collins dalam novel klasik Pride and Prejudice di bawah ini.

\begin{abstract}
"Upon my word, Sir," cried Elizabeth, "your hope is rather an extraordinary one after my declaration. I do assure you that I am not one of those young ladies (if such young ladies there are) who are so daring as to risk their happiness on the chance of being asked a second time. I am perfectly serious in my refusal. You could not make me happy, and I am convinced that I am the last woman in the world who would make you so. - Nay, were your friend Lady Catherine to know me, I am persuaded she would find me in every respect ill qualified for the situation." (Austen, 1813, p. 92).
\end{abstract}

Pengakuan Lizzy tersebut digambarkan sedikit dalam novel mash-up Pride and Prejudice and Zombies, yang dapat dilihat pada kutipan di bawah ini.

\begin{abstract}
"You forget, sir, that I am a student of Shaolin! Master of the seven-starred fist! I am perfectly serious in my refusal.You could not make me happy, and I am convinced that I am the last woman in the world who could make you so. Nay, were your friend Lady Catherine to know me, I am persuaded she would find me in every respect ill qualified for the situation, for I am a warrior, sir, and shall be until my last breath is offered to God" (Austen \& Grahame-Smith, 2009, pp. 85-86).
\end{abstract}

Terlepas dari usahanya untuk menolak lamaran Mr. Collins, perasaan dan pendapat Lizzy tentang masalah tersebut tidak diperhitungkan oleh ibunya, Mrs. Bennet. Fenomena ini disebut sebagai denial of subjectivity seperti yang dikemukakan oleh Nussbaum (1995, p. 257). Dapat dilihat bahwa tidak peduli seberapa keras usaha Lizzy untuk menolak lamaran Mr. Collins, Mrs. Bennet tidak akan memperhitungkan perasaan dan pendapatnya tentang masalah tersebut. Melihat aspek naratif tersebut, dapat diasumsikan bahwa Mrs. Bennet tidak lagi melihat Lizzy sebagai seorang manusia, melainkan sebagai sebuah objek. Seperti sekelompok anak perempuan yang bermain boneka Barbie, mereka tidak akan memperhitungkan bagaimana perasaan boneka Barbie tersebut ketika mereka mainkan. Mirip seperti Lizzy, perasaan dan pendapatnya tidak dianggap penting oleh Mrs. Bennet karena ia bertindak seolah-olah Lizzy tidak kasat mata. Ia tidak memperhitungkan perasaan dan pendapat Lizzy tidak peduli apapun yang terjadi. Ia tidak peduli apakah Lizzy mau menjadi istri Mr. Collins atau tidak, akan tetapi selama anak perempuannya dapat menikahi laki-laki yang bermartabat, Mrs. Bennet akan melakukan segalanya, termasuk mengabaikan bagaimana perasaan dan pendapat Lizzy yang sebenarnya tentang lamaran Mr. Collins.

Selain tokoh utama perempuan yang sama-sama mengalami objectification dalam novel klasik Pride and Prejudice dan novel mash-up Pride and Prejudice and Zombies, tema yang diangkat dalam kedua novel tersebut sama-sama tentang harga diri dan dan prasangka. Diceritakan, Lizzy, sebagai tokoh utama perempuan dalam kedua novel tersebut, memiliki prasangka terhadap Mr. Darcy yang memiliki harga diri yang tinggi. Seiring dengan berjalannya waktu, Lizzy dan Mr. Darcy dapat mengatasi prasangka dan harga diri yang dimiliki masing-masing dan akhirnya menjadi sepasang kekasih yang memutuskan untuk menikah. Sedangkan untuk perbedaan kedua novel tersebut yang mencolok ialah penambahan unsur 
zombie dan bela diri dalam novel mash-up Pride and Prejudice and Zombies. Penambahan unsur modernitas tersebut membuat seolah-olah dengan adanya kemampuan bela diri, anak-anak perempuan keluarga Bennet dapat mempertahankan diri mereka sendiri dari serangan rombie, namun pada akhirnya, mereka tetap tidak bisa mengelak ketika diri mereka mengalami objectification yang dilakukan oleh lawan jenis (khususnya seperti objectification yang dialami oleh Lizzy sebagai tokoh utama perempuan dalam kedua novel tersebut).

\section{PENUTUP}

Objectification biasanya terjadi dalam ranah seksual. Meskipun begitu, perempuan masih dapat mengalami objectification dalam kehidupan sehari-hari. Novel klasik Pride and Prejudice dan novel mash-up Pride and Prejudice and Zombies menyajikan sebuah cerita yang merefleksikan bagaimana perempuan mengalami objectification di luar ranah seksual. Untuk menyimpulkan analisis yang telah dijelaskan sebelumnya, penelitian ini mengungkapkan bahwa terdapat tokoh perempuan yang mengalami objectification di dalam kedua novel tersebut. Tokoh tersebut ialah Elizabeth Bennet, atau yang sering dipanggil Lizzy, yang diperlakukan sebagai sebuah objek oleh Mr. Collins dalam hal instrumentality, fungibility, ownership, dan denial of subjectivity.

Penambahan unsur modernitas seperti adanya zombie dalam novel mash-up Pride and Prejudice and Zombies seolah memunculkan resistansi terhadap objectification, dengan diberikannya kemampuan bela diri pada Lizzy, namun di sisi lain, objectification tersebut masih nyata adanya seperti yang dialami oleh Lizzy. Dalam perspektif sastra bandingan, novel mash-up Pride and Prejudice and Zombies cenderung memiliki ambivalensi meskipun diterbitkan pada era posmodern. Di satu sisi, penambahan unsur bela diri membuat Lizzy mampu mempertahankan dirinya sendiri dari serangan rombie, namun di sisi lain ia masih tetap menjadi korban objectification Mr. Collins. Dengan kata lain, resistansi terhadap objectification dalam novel mash-up Pride and Prejudice and Zombies belum mampu melindungi Lizzy dari objectification yang dilakukan oleh Mr. Collins.

\section{DAFTAR PUSTAKA}

Austen, J. (1813). Pride and Prejudice. London: Wordsworth.

Austen, J., \& Grahame-Smith, S. (2009). Pride and Prejudice and Zombies. Philadelphia: Quirk Books.

Bednarska, D. (2011). A Cripped Erotic: Gender and DIsability in James Joyce's "Nausicaa". James Joyce Quarterly, 49(1), 73-89. Retrieved June 8, 2017, from http://www.jstor.org/stable/245986 94

Betts, C. (2015, October 29). Women and Marriage in the Georgian and Regency Period. Retrieved October 20, 2017, from Charlorre Betts: Historical Novelist:

http://www.charlottebetts.com/wo men-and-marriage/

Chretien, E. (2011). Gentility and the Canon Under Siege: Pride and Prejudice and Zombies, Violence, and Contemporary Adaptations of Jane Austen. Nebraska: Department of English, University of Nebraska.

Ferguson, R. (1992). 'Quick as her Eyes, and as unfix'd as those': objectification and seeing in Pope's "Rape of the Lock". Critical Survey, 4(2), 140-146. Retrieved June 8, 2017, from http://www.jstor.org/stable/415556 44

Gladstein, M. R. (2004). Masculine Sexuality and the Objectification of Women: Steinbeck's Perspective. The Steinbeck Review, 1(1), 109-123. Retrieved June 8, 2017, from 
http://www.jstor.org/stable/415819 52

Jasper, G. M. (2016). Appropriating Austen: Pride and Prejudice and the Feminist Possibilities of Adaptation. California: Scripps College.
Nussbaum, M. (1995). Objectification. Philosophy and Public Affairs, 249-291.

Toth, C. C. (2010). Reanimating Jane: Relevance in Austen's Pride and Prejudice and Seth Grabame-Smith's Zombies. Colorado: Regis University. 